\title{
Interior Galeri Merah Putih sebagai Upaya Optimalisasi Bangunan Cagar Budaya dengan Konsep Entertain Edukatif Bernuansa Kolonial
}

\author{
Rizqy Amelia Putri dan Adi Wardoyo \\ Departemen Desain Interior, Fakultas Teknik Sipil Dan Perencanaan, Institut Teknologi Sepuluh Nopember (ITS) \\ e-mail: rizzuputri@gmail.com
}

\begin{abstract}
Abstrak-Gedung Merah Putih kota surabaya merupakan bangunan dalam kompleks gedung peninggalan bersejarah kolonial Belanda, bernama De Simpangsche Societeit (Simpangsche Club) yang artinya tempat asosiasi kaum elite. De Simpangsche Societeit dibangun pada tahun 1907 oleh Wakan Westmaes dijalan Pemuda. Pada saat itu,tempat ini digunakan untuk pesta dansa, acara minum teh, bowling khusus untuk orang Belanda Gedung. Saat ini Gedung Merah Putih Balai Pemuda di Surabaya merupakan salah satu aset cagar budaya. Hal ini diperkuat dengan adanya SK Walikota Surabaya No. 188.45/251/402/1/04/1996, yang menyatakan Balai Pemuda merupakan bangunan cagar budaya yang dilindungi dengan nomor urut 18 (Bappeda 2004). Gedung Merah Putih Surabaya merupkan hertigae Indonesia yang wajib untuk di lestarikan. Dari aspek ekononomi, gedung merah putih dapat seutuhnya difungsikan sebagai galeri. Dengan mempertimbangkan letak nya yang stategis, site terletak di jantung kota surabaya, merupakan jalan yang sering dilalui orang sehingga cepat menyebarkan informasi. selain itu banyak fasilitas pendukung yang dapat ditemui disekitar gedung balai pemuda, seperti kantor, sekolah pertokan, bank dan sebagainya yang menyebabkan tempat ini sangat strategis Sebelum menentukan konsep desain yang sesuai, dilakukan riset dengan beberapa metode yaitu dengan survey ke lokasi galeri, pembagian kuisioner kepada pengunjung dan wisatawan yang sudah pernah berkunjung ataupun akan berkunjung, pengumpulan literatur, analisis konsep desain, pembuatan konsep, alternatif konsep, gambar kerja, dan hasil akhir 3D. Dari metode-metode tersebut diketahui apa saja kebutuhan pengunjung dan persepsi masyarakat dan wisatawan. Hasil dari metode ini diharapkan dapat memberikan konsep desain yang sesuai untuk Galeri Merah Putih. Mendesain ulang Kantor Merah Putih kota Surabaya dengan interior yang nyaman, edukatif, dan menghibur, tanpa mengurangi nilai sejarah akan menjadi solusi dalam optimalisasi bangunan konservasi sebagai penghasil PAD dan juga mendukung program pemerintah Surabaya sebagai city tour.
\end{abstract}

Kata Kunci-Tuliskan Galeri, Gedung Merah Putih, Kolonial.

\section{PENDAHULUAN}

$\mathrm{G}$ EDUNG Merah Putih Balai Pemuda Surabaya merupakan salah satu bangunan peninggalan kolonial Belanda yang diisukan akan dialihfungsikan dengan pembongkaran. Bangunan yang juga dikenal dengan gedung Merah Putih tersebut dikabarkan akan dibongkar oleh Pemerintah Kota dan digantikan dengan gedung kesenian baru pada awal tahun 2009. Gedung Merah Putih Balai Pemuda di Surabaya merupakan salah satu aset cagar budaya. Hal ini diperkuat dengan adanya SK Walikota Surabaya No. 188.45/251/402/1/04/1996, yang menyatakan Balai Pemuda merupakan bangunan cagar budaya yang dilindungi dengan nomor urut 18. Gedung Merah Putih Surabaya merupkan hertigae Indonesia yang wajib untuk di lestarikan.

Karena komplek Balai Pemuda termasuk gedung merah putih merupakan salah satu penghasil PAD Surabaya, maka kegiatan pokok dari gedung balai pemuda adalah dengan cara menyewakan gedung kepada masayarakat dengan berbagai tujuan, Resepsi Pernikahan, Seminar, Pameran, Audisi Seni, Pagelaran Musik, kantor, perpustakaan, ruang-ruang yang menunjang kegiatan kesenian.

Namun interior dari gedung Merah Putih jika ingin difungsikan sebagai penghasil Pendapatan Daerah masih dianggap kurang optimal. Beberapa area dalam penataan ruangnya tidak tertata rapi, juga tidak tersedianya berbagai fasilitas yang dibutuhkan. Sehingga, tidak sebanding dengan nilai sejarah yang dimiliki oleh gedung Merah Putih itu sendiri.

\section{URAIAN PENELITIAN}

Pada perancangan ini menggunakan metode pengumpulan data kuantitatif dan kualitatif. Pengumpulan data kualitatif seperti analisis data lapangan, dll. Sedangkan pengumpulan data kuantitatif berupa pembagian kuisioner. Berikut tahaptahap perancangan yang dilakukan:

\section{A. Survei Lapangan}

Pada pengumpulan data kualitatif, dilakukan survey lapangan untuk melihat keadaan lapangan yang akan dijadikan objek perancangan, kemudian melihat batasan-batasan wilayah yang berada di sekeliling objek perancangan dan menganalisis hubungannya dengan perancangan yang akan dilakukan nantinya serta mengamati permasalahan-permasalahan yang terjadi di lapangan dan aktifitas manusia yang dilakukan di tempat tersebut sehingga bisa dapat dibuat sebuah desain yang bisa memecahkan persoalan yang terdapat di lapangan.

\section{B. Pembagian Kuesioner}

Setelah melakukan survey, perlu dilakukan pembagian kuisioner untuk mengetahui secara pasti dan akurat tentang kebutuhan yang akan disediakan nantinya. Kuisioner akan dibagi kepada wisatawan, pengunjung dan masyarakat Ponorogo. 


\section{Pengumpulan Literatur}

Mengumpulkan berbagai jenis data tentang GALERI dan potensi pariwisata dan kebudayaan lokal Ponorogo sehingga mempunyai dasar yang kuat dalam mendesain atau merancang sesuatu. Literatur bisa melalui buku dan jurnal ilmiah. Literatur harus berupa karya ilmiah dan bukan karya tulis populer seperti di majalah atau sumber dari internet yang tidak mempunyai sumber yang jelas.

\section{Analisis Konsep}

Setelah melakukan survey dan pengumpulan data yang berupa kuesioner dan literatur, maka akan masuk ke tahap analisis konsep dimana dalam tahap ini akan dirumuskan permasalahan-permasalahan yang ada yang dikumpulkan di tahap kuesioner dan survey lapangan. Dalam tahap ini sudah mulai dipikirkan tentang berbagai konsep desain yang akan menyelesaikan permasalahan yang ada. Konsep desain pada tahap analisis ini masih berupa gambar kasaran dan belum berupa konsep yang lebih detail.

\section{E. Pembuatan Konsep}

Dari tahap analisis kemudian ditemukan gambaran besar tentang konsep perancangan yang akan lebih dirampungkan di tahap ini. Konsep yang akan digunakan nanti akan berpengaruh pada bentukan desain dan luasan desain. Pada tahap ini akan dibuat beberapa alternatif konsep yang akan didiskusikan kepada dosen pembimbing masing-masing konsep manakah yang sesuai.

\section{F. Alternatif Desain}

Setelah menemukan konsep yang sesuai dan sudah rampung, maka akan dibuat beberapa alternatif desain atau skematik desain. Alternatif desain ini bisa berupa sketsa berwarna yang bisa menggambarkan dengan jelas tentang konsep perancangan nantinya.

\section{G. Gambar Kerja}

Setelah desain sudah dirampungkan, maka akan masuk ke tahap gambar kerja dimana desain yang akan dibuat sudah harus detail seperti konstruksi, multiview, material dan rencana anggaran biaya.

\section{H. Perspektif $3 D$}

Setelah didesain selesai dan sudah diasistensi oleh dosen, maka akan dibuat perspektif 3D untuk mengetahui gambaran jelas dari desain akhir.

\section{HASIL DAN ANALISIS}

\section{A. Penerapan Konsep}

Konsep Desain yang dipakai pada perancangan interior Gedung Merah Putih ini adalah Kolonial berkonsep entertain Edukatif. Konsep ini berdasarkan latar belakang masalah yang ada, dimana GALERI yang tidak layak untuk dipakai sebagaimana gedung heritage dengan klasifikasi kelas a tidak dapat diubah karakteristiknya untuk itu entertain edukatif ditonjolkan dari cara penyajian informasi pada galeri merah putih.

\section{B. Perspektif Ruang, Elemen Interior dan Perabot}

Desain interior Galeri, sesuai dengan konsep entertain edukatif dengan molding dan nuansa kolonial. Berikut beberapa desain interior ruang terpilih :

\section{1) Lounge dan Lobby}

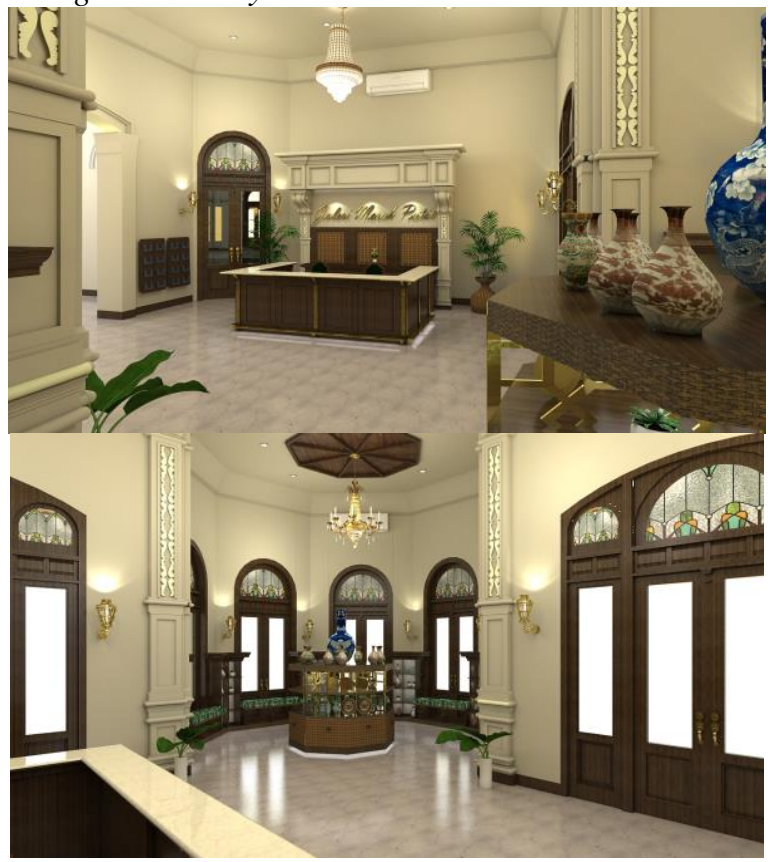

Gambar 1. Perspektif Lobby dan Lounge.

2) Ruang Prangko

Galeri berisi tentang informasi prangko

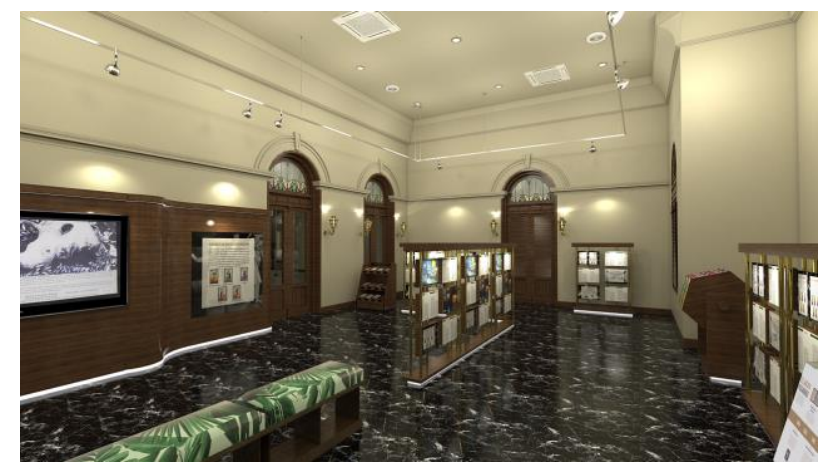

Gambar 2. Galeri.

3) Ruang Pameran

Pameran Merupakan Tempat Eksibisi yang disewakan.

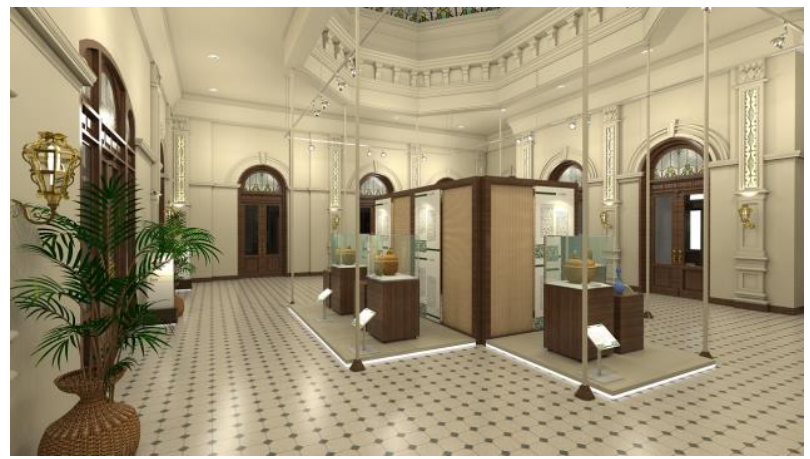

Gambar 3. Ruang Pameran. 


\section{HASIL DAN SARAN}

Dalam merancang, penulis memiliki acuan bahwa, pengunjung dapat teredukasi melalui content dan cara penyajian content yang berada dalam galeri, selain itu penerapan entertain melalui pemenuhan fasilitas turis seperti atm, vending machine, souvenir dan photo booth.

Untuk itu dengan mendesain ulang Kantor Merah Putih kota Surabaya dengan interior yang nyaman, edukatif, dan menghibur, tanpa mengurangi nilai sejarah akan menjadi solusi dalam optimalisasi bangunan konservasi sebagai penghasil PAD dan juga mendukung program pemerintah Surabaya sebagai city tour.

\section{KESIMPULAN/RINGKASAN}

Dalam merancang, penulis memiliki acuan bahwa, pengunjung dapat teredukasi melalui content dan cara penyajian content yang berada dalam galeri, selain itu penerapan entertain melalui pemenuhan fasilitas turis seperti atm, vending machine, souvenir dan photo booth.

Untuk itu dengan mendesain ulang Kantor Merah Putih kota Surabaya dengan interior yang nyaman, edukatif, dan menghibur, tanpa mengurangi nilai sejarah akan menjadi solusi dalam optimalisasi bangunan konservasi sebagai penghasil PAD dan juga mendukung program pemerintah Surabaya sebagai city tour.

[13]

\section{DAFTAR PUSTAKA}

[1] DeChiara. Joseph, P. Julius, and J. Martin, Time Saver. New York: Mc Grew Hill, 2001.

[2] P. Julius and J. Martin, Human Dimension \& Interior Spaces. New York: Potter/TenSpeed/Harmony, 2014.

[3] K. Rina, Konsep Visual Sistem Sarana Isyarat Penunjuk (Sign System) Di Kampus Syahdan Binus University. Vol.1, No.2, pp. 221-232, Oktober 2010.

[4] G. H. Arief, Analisis Pencahayaan Buatan Dan Sirkulasi Pada Area Display Kendaraan Museum Otomotif Sentul, Jurusan Desain Interior Telkom University: Bandung.

[5] R. Ulli Aulia, dan N. Amarena, Penerapan Tipografi Dalam Sistem Signage Pada Interior Ruang Publik, Vol.5, No.2, pp. 822-832, Oktober 2014.

[6] W. Anak Agung Ayu, Dasar-Dasar Perencanaan Interior Museum, Humaniora, Vol.5, No.1, pp. 246-257, April 2014.

[7] P. Theresia, A. Azwar, Al Syafaat, La Ode Abdullah, Kajian Desain Sirkulasi Ruang Dalam sebagai Sarana Evakuasi pada Kondisi Bahaya Kebakaran di Bandung Supermal dan Trans Studio Bandung, Jurusan Teknik Arsitektur ITENAS: Bandung.

[8] Setiowati, Erindiah, \& Saryanto, Tata Cahaya pada Selasar Sunaryo Art Space - Bandung. Jurnal Online Institut Teknologi Nasional: Bandung.

[9] Adysti, N. Listya, Antariksa, Suryasari, Noviani, Pelestarian Gedung Merah Putih Balai Pemuda Kota Surabaya, Arsitektur e-Journal Vol. 4, No.2, UB Malang, Juli 2011.

[10] Surya, G. Gamal, Perancangan Signage Pada Interior Gedung Utama Universitas Esa Unggul. Inosains, Vol. 9, No. 2, Agustus 2014.

[11] SK Walikota Surabaya No. 188.45/251/402/1/04/1996.

[12] Pemerintah Kota Surabaya, Peraturan Perundang- undangan Pemerintah Kota Surabaya No 5 Tahun 2005 tentang Pelestarian Bangunan dan atau Lingkungan Cagar Budaya. 